\title{
Access and allocation in food governance, a decadal view 2008-2018
}

\author{
Dona Azizi ${ }^{1}$ (iD
}

Accepted: 25 April 2020 / Published online: 7 May 2020

(c) The Author(s) 2020

\begin{abstract}
Achieving food security worldwide raises a number of issues with regard to the distribution of global resources. On the one hand, access to resources and ecospace is essential for individuals in order to survive; on the other hand, the allocation of the earth's resources as well as risks and responsibilities are relevant for the global community. Yet, elements of access and allocation are various and complex, encompassing social, environmental, and economic dimensions in an increasingly fragmented global governance structure. Drawing on the multidisciplinary governance framework on access and allocation by Gupta and Lebel, this paper provides a synoptical review of the literature on food security of the past decade from the perspective of the earth system governance scholarship. This article addresses the question: what have we learnt about access and allocation issues in the area of food governance and its implications for food security? In addressing this question, this review examines how institutions, norms and power affect access to and allocation of resources. The paper draws out key trends and lessons from the literature to conclude that research needs to be sensitive to the complexity and intersectionality of food, the systemic challenges that it poses, and the broader political economy around it.
\end{abstract}

Keywords Access and allocation $\cdot$ Food security $\cdot$ Food governance $\cdot$ Food systems

\section{Introduction}

Hunger is on the rise. ${ }^{1}$ In 2017 , nearly 821 million people (about $10.9 \%$ of the world population) faced chronic food deprivation (FAO 2018). Conflict, drought, and disaster linked to climate change are among the factors causing an increase in undernourishment and world hunger. As a response to these developments, food insecurity and the governance of food systems have once again become an important topic for research and policy (Burchi and De Muro 2016; FAO 2018; Godfray et al. 2010).

1 After a period of declining hunger from 2005 to 2014, world hunger is increasing (FAO 2018).

Dona Azizi

d.azizi@uu.nl

1 Copernicus Institute of Sustainable Development, Utrecht University, Princetonlaan 8a, 3584 CB Utrecht, The Netherlands 
In the context of this special issue on access and allocation, this paper provides a synoptical review of the social science literature on food security of the past decade, identifying key trends and lessons learnt. This article is part of a larger assessment process of the first Science and Implementation Plan of the Earth System Governance programme that defined access and allocation as one of its central analytical problems (Biermann et al. 2009a) a decade ago. Following the Access and Allocation framework developed by Gupta and Lebel (2010) in the context of this plan, access relates to the ability of individuals to meet their minimum needs while allocation addresses the distribution of resources, risks, and responsibilities among the global community.

The access and allocation framework helps one to examine if and in how far the literature of the past decade meets more systemic approaches to food security as elaborated by scholars critical about simplistic perspectives on hunger and poverty. In this context, Amartya Sen led by developing systemic ideas on food and hunger four decades ago (Sen 1981). He suggested a comprehensive way to analyze famine, poverty, and resource distribution. When examining the causes of hunger, Sen goes beyond food supply, to consider ownership and exchange of agricultural resources needed for food production and distribution as major analytical elements. Thus, access and allocation are interlinked with such ownership and exchange elements.

This paper is structured as follows. Section 2 describes the Access and Allocation framework as well as the methodology and search criteria for the review. Section 3 on Access and Allocation in the institutions of food governance addresses (1) the shift from food security to food systems, and (2) the development of policy integration concepts as a response to governance fragmentation; an approach which is also implied by the United Nations Sustainable Development Goals. Section 4 examines the selected cross-cutting themes of "norms" and "power" and their impact on Access and Allocation. The final section draws substantive conclusions from the studied literature.

\section{Theory and methods}

This decadal review builds on the framework on Access and Allocation developed by Gupta and Lebel (2010). Drawing on the Earth System Governance concept, the authors point to the ongoing difficulty of allocating global resources among "users and uses" (Gupta and Lebel 2010, p. 377). They argue that distributional issues have two faces. On the one hand, access to sufficient resources and ecospace is essential for the individual to survive; on the other hand, the allocation of the earth's resources as well as risks and responsibilities are relevant for the global community.

These two faces of global distributional problems need to be explored within a multidisciplinary approach to governance. As such, access addresses the question of "whether the basic needs of humans should be met (...) and what instruments can be used to ensure that these needs are met" (Gupta and Lebel 2010, p. 380). Access is defined as the "the ability of individuals to secure a basic minimum of resources and ecospace" (Gupta and Lebel 2010, p. 379). For those with enough financial resources access may be achieved through market mechanisms, whereas those lacking access to these depend on respect for human rights and free or subsidized access to a minimum amount of basic resources, sometimes through appropriate technological options which make these resources cheaper.

The second face, allocation, takes a broader position by looking beyond minimum individual needs and addresses the division of resources among people and states. Following 
the framework, allocation entails three dimensions: First, how resources are shared; second, how risks and burdens are distributed; third, how responsibilities for causing environmental damages are allocated. While the first dimension is about how resources and ecosystem services are shared, the second and third dimensions focus on the way problem situations are handled from the position of the "affected" and those "responsible" (Gupta and Lebel 2010, p. 379).

Based on the Access and Allocation framework, this review conducted a range-specific and target-focused study of academic literature on food security for the past decade. The scope of this study is a review of publications from the broader community of scholars working on food security from an Earth System Governance perspective.

In order to collect the literature, publications related to food security were retrieved from the scientific data base "Scopus" which includes various publishers, such as Elsevier, Springer, Wiley, Sage, and others. Publication types searched for on Scopus were peerreviewed publications. The search was based on the search terms "food security" AND "governance" as well as "food governance" and "food systems" in the article title (and related keywords, e.g., land use, biodiversity, etc.) and four inclusion criteria: (1) the limitation of the publication period to the years 2008 to 2018, (2) the categorization of the publication in the discipline of social science, ${ }^{2}(3)$ the limitation of document types to articles, book chapters, books, and reviews (and not papers of proceedings or other types of documents such as book reviews), and (4) the language restriction to English. I identified 106 papers for a thorough review.

For reviewing the literature, this paper followed a thematic approach which allowed to create a synopsis based on (1) institutional aspects and the conceptualization of food security and (2) the selected cross-cutting themes "norms" and "power." These focus points represent major elements relevant for reviewing and comparing publications addressing access and allocation in food security. This summary contains information which is explained in each indicated section throughout the article.

\section{Access and allocation in the institutions of food governance}

\subsection{1 From food security to food systems}

A key event of the past decade was the global financial crisis from 2007 to 2008, which affected the dynamics of poverty, hunger and malnutrition (Burchi and De Muro 2016; Leventon and Laudan 2017; Lipton and Saghai 2017; Moragues-Faus 2017). In response, the literature developed more advanced approaches to food security, especially as part of food systems. This section elaborates on the key aspects of access and allocation in food systems as identified by the selected literature.

The concept of food security has emerged and expanded over recent decades (Du and King 2018; Lang and Barling 2012; McMichael 2014). It has been transformed from being limited to an agricultural issue that required increased food production to a systems perspective that considers food (in)security as "a complex array of problems, not just production" (Lang and Barling 2012).

\footnotetext{
${ }^{2}$ This inclusion criterion was set in order to narrow down the publications to those with relation to governance.
} 
This transformation saw food systems as "highly complex and distanced" constructs (Clapp and Scott 2018, p. 3) within which access and allocation are interlinked with global economic relationships, including production, agricultural commodity trade, markets, communities, food processing, retail and distribution, and consumption (Herforth et al. 2014; Hospes and Brons 2016; Olson et al. 2014; Vermeulen et al. 2012). This underlying structure of the global system which leads to a physical and mental separation of production and consumption (Clapp 2015; Clapp and Scott 2018) has devastating consequences for the global poor (Lang and Barling 2012; Terlau et al. 2018).

Access is affected as poor population groups are often unable to grow food because land is increasingly degraded and negatively impacted by climate change, as both the literature (Foley et al. 2011; Gomiero 2016; Poesen 2018) and reports from international institutions underline: Land degradation and climate change imply that the land is often relatively unproductive and this affects some 3.2 billion people worldwide (UNCCD 2017). ${ }^{3}$ Annually, $12 \mathrm{M}$ hectares of forest land have been degraded (FAO 2015) which directly affects indigenous and local peoples. These population groups also face concerns of declining land species populations by 38\% between 1970 and 2012 (WWF 2016).

The inability of poor people to grow or buy the food they need is exacerbatd by so-called land-grabbing (Borras et al. 2015, 2011; De Schutter 2011; Golay and Biglino 2013). The land-grabbing phenomenon is a "widespread, rapid increase in commercial land transactions that involve the acquisition or long-term lease of large areas of land by investors" (Golay and Biglino 2013, p. 1630). Land-grabbing occurs increasingly in a globalizing world where richer people can purchase land from poorer local people. This further marginalizes the poor, as shown by data from various international organizations. While 2.5 billion people directly depend on land, only 10\% own it (Oxfam 2016a, b). These conditions affect particularly women: over 400 million female farmers possess only $20 \%$ of the land they use for agriculture (FAO 2011a); further, in 90 countries, social customs do not allow women to own land (Gupta et al. 2020). With 276 new deals between 2012 and 2016, land-grabbing caused income losses for 12 million-mostly poor-people (Nolte et al. 2016). Local farmers face the largest problems of such dispossessions (42\% of all landgrabbing deals are in Africa) (Nolte et al. 2016).

Addressing the challenges of land degradation and land-grabbing by institutions is critical, yet they often fail to support the poor as they are unable to stop the land degradation and land-grabbing and to adequately subsidize food. Thus, addressing food security also requires focusing on the particular needs of smallholder farmers, indigenous people, fishermen, and pastorialists. Each of these communities has different challenges in achieving food security and also have different customary practices. Capitalist Western-style approaches, especially private ownership of land and market-determined land reforms that facilitate private capital accumulation usually do not meet the socioeconomic realities of non-Western people (De Schutter 2010).

In many countries, people face insecure property rights, tight legal constraints and poor contract enforcement which altogether creates an unequal access to land. Land reform is often recommended for minimalizing such inequalities in land distribution (Lipton 2009; Lipton and Saghai 2017). Following Lipton (2009, p. 1), "land reform compromises laws with the main goal of reducing poverty by substantially increasing the proportion of farmland controlled by the poor, and thereby their income, power or

\footnotetext{
3 It is estimated that $50 \%$ of the world's hungry are smallholder farmers, $20 \%$ landless people and $10 \%$ herders, pastoralists or fisherfolk (UNDP 2005, pp. 4-6).
} 
status." Ways of supporting smallholder farmers is to provide measures for providing credits and to create "safety nets" (World Bank 2008, p. 9). Land reform can also facilitate entrance options for smallholders into the market, improve productivity and support women's rights (ibid.). However, poverty reduction and rural development may be less dependent on land reform, but rather on liberal macro-economic policies and access to health and education for larger population groups (Lipton 2009).

Often, the form of such land possession may lead to the creation of private property and individual rights, including the right to alienate. This promotes land commodification or the transformation of land into a profitable asset (Borras et al. 2015). Some commentators suggest that states should grant the development of a human right to land and to develop policies and strategies that meet such realities by acknowledging different categories of land use including making space for communal property (De Schutter 2011).

Yet, the adoption of the human right to food which imposes some responsibilities on the state is inadequately being enforced. The state often fails to ensure that individuals can access resources necessary for producing food for themselves (obligation to respect), that they can protect such access from being infringed by other private parties (obligation to protect), and that they can pursue access to and utilization of resources and instruments to secure their livelihoods, especially food security (obligation to fulfil) (Golay and Biglino 2013). The state needs to realize these obligations as a way to ensure that people access food.

Allocation is affected by international trade, which significantly redefines the distribution of resources in terms of an increasingly geographical disconnection of food production and consumption (Clapp and Scott 2018) and a strong reliance of poor countries on richer states (Clapp and Fuchs 2009). Amplified by the food crisis, international trade grew in importance for meeting the demand for agricultural products and in 2013, 16\% of the world population covered its demand through food imports (Fader et al. 2013). For the global poor, increasing international trade becomes problematic as they rely on the "political, environmental, demographic and economic situation in the exporting countries that might choose or be forced to alter the supply available to the market" (Fader et al. 2013, p. 2).

The global poor are especially challenged by the impact of international trade on the volatility of food prices. In most developing countries, as many households are both producers and buyers of agricultural products (FAO 2011b), price volatilities have often severe impacts on food security. In less developed countries, poor consumers "without access to social support are most immediately affected by price surges" (FAO 2011b, p. 7). Yet, also producers, especially smallholder farmers, are affected by low prices as their income level is too low to allow for providing the farm family with resources or the operational functions of the farm (FAO 2011b). This is problematic as about $75 \%$ of the global agricultural land is operated by family farms while farm sizes in low-income countries are decreasing (Lowder et al. 2016).

High food prices cause difficulties for the global poor to produce crops in their own territory and with their own land and water as it leaves them unable to purchase agricultural resources (Ringler et al. 2013). Hence, "up to about 5.2 billion (51\% of world population)" (Fader et al. 2013, p. 4) depend on "ex situ" land and water resources. The impact of high food prices on poor people is amplified by an increasing competition over land and water resources needed for the production of crop for biofuels (Koh and Ghazoul 2008; Sorda et al. 2010; Tilman et al. 2009; Tomei and Helliwell 2016). The production of biofuel crops has led to discussions about the numbers of people that could be fed by crops and croplands that are now used for biofuels. The question is whether biofuel crops could 
reduce malnutrition, if used for food consumption (Meyfroidt et al. 2013; Tomei and Helliwell 2016).

The financial crisis resulted in significant food price volatility leading to poor, financially vulnerable consumers and producers that face extensive economic, political and social issues due to high prices and fears of resource shortage (FAO 2011b; Maetz et al. 2011). Food expenses are a significant part of the budget of poor households. As poor households usually consume less processed food products, "the effect of rises in commodity prices is felt more strongly" (FAO 2011b, p. 6). When food prices are high, such households see themselves forced to compromise their basic needs, including their nutrition status, health care, and options to purchase education (FAO 2011b). Food price spikes resulting from the food crisis have halted governments from imposing measures, including bans, higher taxes, restrictions, and quotas on exports in various countries (Fader et al. 2013; Maetz et al. 2011), putting further pressure on poor countries to allocate sufficient amounts of food among people.

Additionally, unstable and uncertain climate conditions and a variety of financial agents in commodity markets contribute to the instability of food markets (Clapp and Scott 2018). Furthermore, distanced food supply chains allow agents to externalize costs in the supply chain due to little exchange of information as "products change hands" (Clapp and Scott 2018 , p. 3). This has consequences for food allocation as it is difficult to prescribe responsibilities for environmental damage in the food system. Past literature often suggested that diseases related to contaminated food and water would decline worldwide with improvements in production and marketing of safe food for developed countries which would also benefit producing countries of the developing world. However, the safety of food "remains a dynamic situation heavily influenced by multiple factors along the food chain from farm to fork" (Newell et al. 2010, p. 3).

The literature suggests that institutions should manage food demand through dietary changes towards less resource-consuming products, or alternatively, increase international trade (Fader et al. 2013). Institutions should also enhance productivity, especially in Africa and the Middle East to enable populations access a minimum amount of calories of healthy food. However, up to 1.3 billion people "may be at risk of food insecurity in 2050 in present low-income economies (mainly in Africa), if their economic development does not allow them to afford productivity increases, cropland expansion and/or imports from other countries" (Fader et al. 2013, p. 5).

\subsection{Policy integration in food security governance}

In the context of the global financial crisis from 2007 to 2008, the literature not only highlighted the systemic nature of food security, but also focused on the governance of the complex institutional landscape of food security. They focused on policy integration (also known as policy coherence or policy mainstreaming). Policy integration is identified as central for tackling fragmented global governance structures, recognized as "policy silos" (Obersteiner et al. 2016). Policy integration has been adopted by the Sustainable Development Goals, which "call for a comprehensive new approach to development rooted in planetary boundaries, equity, and inclusivity" (Obersteiner et al. 2016, p. 1).

Access and allocation are integral parts of policy integration concepts (Rasul 2016; Weitz et al. 2017), which address the growing cross-scale and cross-sector interactions that have emerged in the context of the global financial crisis (Allouche et al. 2014) and as a result of increasing natural resource scarcity (Ringler et al. 2013). Since then, scholars 
have pointed to the need for policy integration to address food security, often associated with the nexus across food, water, energy, and land (Biggs et al. 2015; Boas et al. 2016; Leck et al. 2015; Pahl-Wostl 2019; Ringler et al. 2013).

More broadly, policy integration responds to a fragmented governance structure (Biermann 2007; Biermann et al. 2009b; Boas et al. 2016; Weitz et al. 2017; Zelli and van Asselt 2013) where policies on different subject areas are not integrative, but separate from each other. Each sector has its specific sets of actors, objectives and discourses (McKeon 2011). Consequently, mandates and actions overlap, which can duplicate actions or have conflicting interests, paradigms, and visions (Margulis 2012, 2013; McKeon 2011). This fragmentation is problematic as it leads to many different initiatives and projects which cannot be scaled up to make a difference (Candel 2014; Committee on World Food Security 2012).

In addressing this governance challenge, policy integration is expected to identify synergies and trade-offs between different sectors (Weitz et al. 2017). Yet, the literature offers different perspectives regarding the need for policy integration in food security governance.

One perspective addresses the allocation aspects related to risks and security. The limited interconnections between sectors exacerbates resource scarcity and creates political and economic conflicts (Bizikova et al. 2013) such as the risk that first-generation biofuel poses to food security (Rulli et al. 2016). The second perspective aims at optimizing resource allocation across different food-related sectors in order to reduce policy costs and to increase resource use efficiency (Ringler et al. 2013; Weitz et al. 2017). The third perspective views policy integration as an administrative issue (Allouche et al. 2014; Rees 2013) and argues that addressing trade-offs and improving policy integration across foodrelated sectors emerge from a political negotiation process shaped by different interests, practices and perceptions. Questions on equity and justice as part of this social process are therefore central for the fulfillment of policy integration which may have unintended consequences for other policy fields, such as education or poverty reduction (Jobbins et al. 2015).

A recent global policy addressing fragmentation and pursuing food security is the 2030 Agenda on Sustainable Development adopted in 2015 by the United Nations General Assembly (UNGA 2015) as the follow-up to the Millennium Development Goals (2000-2015) (United Nations 2000). The Agenda includes 17 Sustainable Development Goals (SDGs) as an integrative package deal (Azizi et al. 2019), formulating "conditions for sustainable management of social, physical, and ecological elements of the Earth system in the Anthropocene" (Obersteiner et al. 2016, p. 1).

The literature considers the major transformative power of the SDGs in identifying and integrating interdependencies among its various goals and in operationalizing them (Agarwal 2018; Azizi et al. 2019; Giupponi and Gain 2017; Obersteiner et al. 2016; PérezEscamilla 2017; Rasul 2016). Especially food security requires ascertaining whether the "direct and and indirect effects of policies in service of specific goals can affect the success or failure of others" (Obersteiner et al. 2016, abstract; Foley et al. 2011; Nilsson and Persson 2012). The literature points to the systematic and integrative way in which food security is addressed by the Agenda, including its various social, environmental, and economic aspects regarding access and allocation. Not only Goal 2 (End hunger, achieve food security and improved nutrition, and promote sustainable agriculture) explicitly refers to food, but the remaining 16 goals also indirectly address this subject (Pérez-Escamilla 2017). For example, Goal 13 (Take urgent action to combat climate change and its impacts) relates to increased risks of food insecurity due to environmental degradation caused by climate change while at the same time food insecurity is considered to lead to social and environmental disruption which again accelerates climate change (Pérez-Escamilla 2017). 
Access is affected as the Agenda offers opportunities to support the individual's right to agricultural resources through financial instruments (Markelova and Mwangi 2010; Olomola 2013; Terlau et al. 2018). Smallholder farmers often cannot claim land and water as they cannot meet the strict conditions for accessing loans (Goal 9.3) (Terlau et al. 2018; Warnecke 2015). This is caused by a "lack of asset ownership to serve as collateral (wealth rationing) and in the ability to put assets at risk as collateral when they are vital to livelihoods (risk rationing)" (World Bank 2008, p. 13). Further, smallholder farmers suffer from a limited access to agricultural equipment, such as machinery or fertilizer while particularly female farmers face poor access to markets (SDG 5.a) (Gupta et al. 2020; Phiri et al. 2019; Terlau et al. 2018).

Allocation aspects touched on by the Agenda are various; however, authors identify the cross-sectoral management of risks as a central aspect in the context of food (Griggs et al. 2013, 2014; Kelman 2017; Lobell et al. 2008; Whitmee et al. 2015). Such risks include the fact that the poor are often exposed to uninsured risks which result from health shocks, natural catastrophies, demographic changes, policy changes, and price volatility (FAO 2011b; Lesk et al. 2016; Vermeulen et al. 2012; World Bank 2008). In order to manage risks, affected population groups would need higher incomes (Vermeulen et al. 2012). This comes along with the need to acquire assets, especially agricultural land, which would allow them to build security in case of shocks caused by decapitalization (Keesstra et al. 2018). Further, health (Goal 3) and primary education (Goal 4) can be negatively impacted if children are not able to attend school as a result of shocks or if they are affected by early malnutrition (Goal 2), which in the long term leads to generational heritage of poverty (Goal 1) (Seligman et al. 2010; World Bank 2015).

\section{Cross-cutting issues of food security}

\subsection{Food sustainability as a key norm of earth system governance}

Sustainability identified as a norm is "relevant at all levels of decision-making in earth system governance" (Biermann et al. 2009a, p. 72). This is emphasized by various authors who observe that food security, agriculture, and sustainability are increasingly discussed in the same context (Allen and de Brauw 2018; Fanzo et al. 2018; Richardson 2010; Smith and Gregory 2013).

Food sustainability ${ }^{4}$ and food security have a reciprocal relationship since food security is seen as a condition for sustainability while sustainability is required for achieving longterm food security (Berry et al. 2015). However, unsustainable practices of intensive and extensive agricultural production generates environmental problems, such as the loss of biodiversity, mismanaged irrigation water, agro-chemical pollution, and health costs and deaths from pesticide poisoning (World Bank 2008). By 2050, food production is expected to rise by $60-100 \%$ through intensive agriculture (Tilman et al. 2011), at the possible cost of damage to assets owned by indigenous and local people resulting in large losses (Gupta et al. 2020).

\footnotetext{
${ }^{4}$ Following Lang and Barling (2012, p. 322), 'food sustainability' is focused on the requirement "Food systems must be designed to exist for the long-term."
} 
These ecological and social issues are addressed by the literature on transitions towards sustainable food provision. Optimistic authors argue that the transition from conventional food production to sustainable food production will lead to more food availability, improved access to food, a better utilization of food, and an increased food system stability (Garnett et al. 2013). Skeptical scholars explain that current agricultural practices and the search for food security may undermine the transition towards a sustainable food system and agriculture (Audet et al. 2017; Bommarco et al. 2013). Unsustainable practices in intensive and extensive farming areas are, for example, inappropriate subsidy and pricing policies that hinder effective management of externalities or poor property rights which create disincentives for natural resource management (Sikor et al. 2017; Tilman et al. 2011).

Access problems which have emerged because of unsustainable agriculture are the exposure of poor people to degraded land and pollution caused by agricultural processes, and the vulnerability and displacement of individuals caused by land-grabbing, biodiversity loss, and climate variability and change (World Bank 2008). Access issues are further amplified by livestock production, which uses 70\% of agricultural land (World Bank 2008), causes deforestation as a driver of land use change (Machovina et al. 2015), produces 18\% of greenhousegas emissions (FAO 2006), is the key sector of biodiversity damage, and is the "largest sectoral source of pollutants" (Gupta et al. 2020, p. 508), including animal wastes, the spread of animal diseases (World Bank 2008), chemicals, hormones and antibiotics, fertilizers, coral reef damage, etc. (FAO 2006) which altogether are particularly problematic for people in populated and peri-urban areas (Holden and Otsuka 2014).

Allocation problems relate to the causation of harm via soil pollution or food contaminators and the mismanagement of risk regarding the usage of pesticides and other pollutants. Many areas are affected by deforestation, desertification, soil erosion, degradation of pastures and watersheds. For example, in the East African highlands, "soil erosion can result in productivity losses as high as $2-3 \%$ a year, in addition to creating offsite effects such as the siltation of reservoirs" (World Bank 2008, p. 16).

Overall, food security is increasingly linked to sustainability, but the literature on transitions of sustainable food production that considers aspects of food security in depth is limited. Also, transformations of food systems that could lead transitions to sustainable food production is limited in research.

\subsection{Power}

The literature has often pointed to the global character of the food system where occurances in "one part of the world can have multiple and wide-ranging impacts" (Clapp and Fuchs 2009, p. 1), as demonstrated by the systemic feedback of food price volatility during the financial crisis. In this global food system, transnational corporations (TNCs) are the most powerful actors (Clapp and Fuchs 2009; Fuchs et al. 2016; Fuchs and Kalfagianni 2010; Kalfagianni and Skordili 2019). They play a key role in the international trade of food and agricultural products and control various stages of the food value chain, including production, distribution, processing, and are central retailers that govern consumption, particularly in developed countries (Biermann 2007; Clapp and Fuchs 2009; Gumbert and Fuchs 2018).

Yet, despite their vast political influence, literature on the power-related aspects of TNCs in this field is limited. Existing literature mostly focuses on the market power of TNCs and other corporate agents (Clapp and Fuchs 2009) and trade relations between developed and developing countries (Lang and Barling 2012). However, understanding 
the corporate power of TNCs requires more systemic analysis of the political power that corporations can exercise in global food governance (Lang and Barling 2012). More systemic and comprehensive analysis is necessary because TNCs have "stretched their operations both vertically and horizontally, to the point that it no longer makes sense to speak of national food systems" (Clapp and Fuchs 2009, p. 4). Extreme concentrations among multi and transnational corporations dominate the global food business from production to distribution (Clapp 2018; Clapp and Scott 2018; Howard 2016; Murphy et al. 2012). Research on corporate power would provide a better understanding of the socially and physically distanced relationship of production and consumption of food (see Sect. 3.1) dominated by TNCs.

Corporate power affects the allocation of resources such as land and the purchasing power of people (Lang and Barling 2012). This results in unequal shares between richer and poorer countries as TNCs, usually located in developed states, exercise their power by steering policy-making through international institutions, especially the World Trade Organization, Group of 8 and Group of 20 (Margulis 2013). They shape the global food system and food security governance based on their own interests and preferences and are supported by their structural power: Through lobbying and public relations activities they are able to frame food policy and governance for the public eye (Fuchs et al. 2016) and promote their own agricultural and trade interests (Clapp 2017; Clapp and Scott 2018). Corporate actors are increasingly playing a role in earth system governance through voluntary sustainable certification systems, the participation in emission reduction programmes and funding of environmental research and conservation of biodiversity (Folke et al. 2019; Vandergeest 2017). In this process of lobbying and enforcing national and corporate interests, they disregard aspects of equity, justice, participation, and social inclusion for poor people and states (Kalfagianni 2015; Kennedy and Lilijeblad 2016).

\section{Conclusions}

This article has focused on the issues of access and allocation in the field of food security identified by literature of the Earth System Governance scholarship of the past decade. Based on a synoptical review, three central lessons can be drawn. First, the reviewed literature has shown that the degree of complexity around the subject area of food has drastically increased over the past decade, with a particular shifting notion on access and allocation. In the past, the issue of food insecurity has often been dealt with in an isolated way and was to be solved through increased food production. Such an understanding is moving to the emerging concept of food systems. Key to this shift is the acknowledgement of interconnections between social, environmental, and economic dimensions in the field of food in a widely fragmented governance structure. As a response to this fragmentation, policy integration has been developed which aims to better integrate food with other environmental issue areas.

The literature also highlights that food security is also inextricably linked with food sustainability. Rather than viewing the two as separate aspects, environmental well-being is a key condition for access to healthy and nutritious food. In this context, allocation mechanisms that ensure fair distribution of rights to land and water, but also that set caps to emissions, waste, pesticide use, and other types of pollution are crucial for both food security and food sustainability. 
A relatively small part of the literature addresses questions of power in the food system. This is problematic as power, largely concentrated in the retail end of global supply chains, has huge implications both for access and allocation of food. Indeed, access is constrained when big corporate actors determine who has the "licence to produce" (Fuchs et al. 2009) for global food markets. Simultaneously, due to the transnational nature of global supply chains it is mostly corporate actors rather than governments who make the decisions about allocation mechanisms among supply chain actors in terms of who gets what and why.

Looking forward to the next decade, questions of food access and allocation remain relevant. Global institutional responses, such as the Sustainable Development Goals, may provide new avenues for cooperation at different levels of governance which could alleviate some of the current concerns. A future research agenda needs to be sensitive to the complexity and intersectionality of food, the systemic challenges that it poses, and the broader political economy around it.

\section{Compliance with ethical standards}

Conflict of interest The author declares no conflict of interest.

Open Access This article is licensed under a Creative Commons Attribution 4.0 International License, which permits use, sharing, adaptation, distribution and reproduction in any medium or format, as long as you give appropriate credit to the original author(s) and the source, provide a link to the Creative Commons licence, and indicate if changes were made. The images or other third party material in this article are included in the article's Creative Commons licence, unless indicated otherwise in a credit line to the material. If material is not included in the article's Creative Commons licence and your intended use is not permitted by statutory regulation or exceeds the permitted use, you will need to obtain permission directly from the copyright holder. To view a copy of this licence, visit http://creativecommons.org/licenses/by/4.0/.

\section{References}

Agarwal, B. (2018). Gender equality, food security and the sustainable development goals. Current Opinion in Environmental Sustainability, 34, 26-32. https://doi.org/10.1016/j.cosust.2018.07.002.

Allen, S., \& de Brauw, A. (2018). Nutrition sensitive value chains: Theory, progress, and open questions. Global Food Security, 16, 22-28. https://doi.org/10.1016/j.gfs.2017.07.002.

Allouche, J., Middleton, C., \& Gyawali, D. (2014). Nexus Nirvana or Nexus Nullity? A dynamic approach to security and sustainability in the water - energy - food Nexus, STEPS Working Paper 63. STEPS Centre, Brighton, UK.

Audet, R., Lefèvre, S., Brisebois, É., \& El-Jed, M. (2017). Structuring tensions and key relations of montreal seasonal food markets in the sustainability transition of the agri-food sector. Sustainability, 9, 320. https://doi.org/10.3390/su9030320.

Azizi, D., Biermann, F., \& Kim, R. (2019). Policy integration for sustainable development through multilateral environmental agreements. Global Governance: A Review of Multilateralism and International Organizations, 25, 445-475. https://doi.org/10.1163/19426720-02503005.

Berry, E. M., Dernini, S., Burlingame, B., Meybeck, A., \& Conforti, P. (2015). Food security and sustainability: Can one exist without the other? Public Health Nutrition, 18, 2293-2302. https://doi. org/10.1017/S136898001500021X.

Biermann, F. (2007). 'Earth system governance' as a crosscutting theme of global change research. Global Environmental Change, 17, 326-337. https://doi.org/10.1016/j.gloenvcha.2006.11.010.

Biermann, F., Betsill, M., Gupta, Joyeeta, J., Kanie, N., Lebel, L., Liverman, D. M., Schroeder, H., \& Siebenhühner, B. (2009a). Earth System Governance. People, Places, and the Planet. Science and 
Implementation Plan of the Earth System Governance Project (IHDP Report 20), Earth System Governance Report 1. The Earth System Governance Project, Bonn.

Biermann, F., Pattberg, P., van Asselt, H., \& Zelli, F. (2009). The fragmentation of global governance architectures: A framework for analysis. Global Environmental Politics, 9, 14-40. https://doi.org/10.1162/ glep.2009.9.4.14.

Biggs, E. M., Bruce, E., Boruff, B., Duncan, J. M. A., Horsley, J., Pauli, N., et al. (2015). Sustainable development and the water-energy-food nexus: A perspective on livelihoods. Environmental Science \& Policy, 54, 389-397. https://doi.org/10.1016/j.envsci.2015.08.002.

Bizikova, L., Roy, D., Swanson, D., Venema, H.D., McCandless, M., 2013. The water-energy-food security Nexus: Towards a practical planning and decision-support framework for landscape investment and risk management.

Boas, I., Biermann, F., \& Kanie, N. (2016). Cross-sectoral strategies in global sustainability governance: Towards a nexus approach. International Environmental Agreements: Politics, Law and Economics, 16, 449-464. https://doi.org/10.1007/s10784-016-9321-1.

Bommarco, R., Kleijn, D., \& Potts, S. G. (2013). Ecological intensification: Harnessing ecosystem services for food security. Trends in Ecology \& Evolution, 28, 230-238. https://doi.org/10.1016/j. tree.2012.10.012.

Borras, S. M., Franco, J. C., \& Suárez, S. M. (2015). Land and food sovereignty. Third World Quarterly, 36, 600-617. https://doi.org/10.1080/01436597.2015.1029225.

Borras, S. M., Hall, R., Scoones, I., White, B., \& Wolford, W. (2011). Towards a better understanding of global land grabbing: An editorial introduction. Journal of Peasant Studies, 38, 209-216. https://doi. org/10.1080/03066150.2011.559005.

Burchi, F., \& De Muro, P. (2016). From food availability to nutritional capabilities: Advancing food security analysis. Food Policy, 60, 10-19. https://doi.org/10.1016/j.foodpol.2015.03.008.

Candel, J. J. L. (2014). Food security governance: A systematic literature review. Food Security, 6, 585-601. https://doi.org/10.1007/s12571-014-0364-2.

Clapp, J. (2018). Mega-mergers on the menu: Corporate concentration and the politics of sustainability in the global food system. Global Environmental Politics, 18, 12-33. https://doi.org/10.1162/ glep_a_00454.

Clapp, J. (2017). The trade-ification of the food sustainability agenda. The Journal of Peasant Studies, 44, 335-353. https://doi.org/10.1080/03066150.2016.1250077.

Clapp, J. (2015). Distant agricultural landscapes. Sustainability Science, 10, 305-316. https://doi. org/10.1007/s11625-014-0278-0.

Clapp, J., \& Fuchs, D. A. (Eds.). (2009). Corporate power in global agrifood governance, food, health, and the environment. Cambridge, Mass: MIT Press.

Clapp, J., \& Scott, C. (2018). The global environmental politics of food. Global Environmental Politics, 18, 1-11. https://doi.org/10.1162/glep_a_00464.

Committee on World Food Security. (2012). Global Strategic Framework for Food Security and Nutrition. Rome: CFS. http://www.fao.org/fileadmin/templates/cfs/Docs1112/WGs/GSF/MD976E_GSF_Draft _Two.pdf. Accessed 29 June 2019.

De Schutter, O. (2011). How not to think of land-grabbing: Three critiques of large-scale investments in farmland. Journal of Peasant Studies, 38, 249-279. https://doi.org/10.1080/03066150.2011.559008.

De Schutter, O. (2010). The emerging human right to land. International Community Law Review, 12, 303334. https://doi.org/10.1163/187197310X513725.

Du, J., \& King, C. (2018). Unravelling China’s Food Security Puzzle, 1979-2008. The China Quarterly, 235, 804-827. https://doi.org/10.1017/S0305741018000917.

Fader, M., Gerten, D., Krause, M., Lucht, W., \& Cramer, W. (2013). Spatial decoupling of agricultural production and consumption: Quantifying dependences of countries on food imports due to domestic land and water constraints. Environmental Research Letters, 8, 014046. https://doi.org/10.1088/17489326/8/1/014046.

Fanzo, J., Davis, C., McLaren, R., \& Choufani, J. (2018). The effect of climate change across food systems: Implications for nutrition outcomes. Global Food Security, 18, 12-19. https://doi.org/10.1016/j. gfs.2018.06.001.

FAO. (2006). Livestock's long shadow: Environmental issues and options. Rome: FAO.

FAO. (2011). The state of food and agriculture 2010-2011: Women in agriculture. Rome: FAO.

FAO. (2011). Price volatility in food and agricultural markets: Policy responses. Rome: FAO.

FAO. (2015). Global forest resources assessment. Rome: FAO.

FAO (2018). The State of Food Security and Nutrition in the World 2018. https://www.fao.org/state-offood-security-nutrition/en/. Accessed 07 May 2019. 
Foley, J. A., Ramankutty, N., Brauman, K. A., Cassidy, E. S., Gerber, J. S., Johnston, M., et al. (2011). Solutions for a cultivated planet. Nature, 478, 337-342. https://doi.org/10.1038/nature10452.

Folke, C., Österblom, H., Jouffray, J.-B., Lambin, E. F., Adger, W. N., Scheffer, M., et al. (2019). Transnational corporations and the challenge of biosphere stewardship. Nature Ecology \& Evolution, 3, 1396-1403. https://doi.org/10.1038/s41559-019-0978-z.

Fuchs, D., Di Giulio, A., Glaab, K., Lorek, S., Maniates, M., Princen, T., et al. (2016). Power: The missing element in sustainable consumption and absolute reductions research and action. Journal of Cleaner Production, 132, 298-307. https://doi.org/10.1016/j.jclepro.2015.02.006.

Fuchs, D., \& Kalfagianni, A. (2010). The causes and consequences of private food governance. Business and Politics, 12, 1-34. https://doi.org/10.2202/1469-3569.1319.

Fuchs, D., Kalfagianni, A., \& Arentsen, M., (2009). Retail power, private standards, and sustainability in the global food system. In J. Clapp, \& D. Fuchs(Eds.), Corporate Power in Global Agrifood Governance (pp. 28-59). The MIT Press. https://doi.org/10.7551/mitpress/9780262012751.003.0002.

Garnett, T., Appleby, M. C., Balmford, A., Bateman, I. J., Benton, T. G., Bloomer, P., et al. (2013). Sustainable intensification in agriculture: Premises and policies. Science, 341, 33-34. https://doi.org/10.1126/ science. 1234485.

Giupponi, C., \& Gain, A. K. (2017). Integrated spatial assessment of the water, energy and food dimensions of the sustainable development goals. Regional Environmental Change, 17, 1881-1893. https://doi. org/10.1007/s10113-016-0998-z.

Godfray, H. C. J., Beddington, J. R., Crute, I. R., Haddad, L., Lawrence, D., Muir, J. F., et al. (2010). Food security: The challenge of feeding 9 billion people. Science, 327, 812-818. https://doi.org/10.1126/ science. 1185383.

Golay, C., \& Biglino, I. (2013). Human rights responses to land grabbing: A right to food perspective. Third World Quarterly, 34, 1630-1650. https://doi.org/10.1080/01436597.2013.843853.

Gomiero, T. (2016). Soil degradation, land scarcity and food security: Reviewing a complex challenge. Sustainability, 8, 281. https://doi.org/10.3390/su8030281.

Griggs, D., Stafford-Smith, M., Gaffney, O., Rockström, J., Öhman, M. C., Shyamsundar, P., et al. (2013). Sustainable development goals for people and planet. Nature, 495, 305-307. https://doi. org/10.1038/495305a.

Griggs, D., Stafford Smith, M., Rockström, J., Öhman, M. C., Gaffney, O., Glaser, G., et al. (2014). An integrated framework for sustainable development goals. Ecology and Society. https://doi.org/10.5751/ ES-07082-190449.

Gumbert, T., \& Fuchs, D. A. (2018). The power of corporations in global food sector governance. In A. Nolke \& C. May (Eds.), Handbook of the International Political Economcy of the Corporation (pp. 435-447). Cheltenham: Edward Elgar Publishing.

Gupta, J., \& Lebel, L. (2010). Access and allocation in earth system governance: Water and climate change compared. International Environmental Agreements: Politics, Law and Economics, 10, 377-395. https://doi.org/10.1007/s10784-010-9139-1.

Gupta, J., Scholtens, J., Perch, L., Dankelman, I., Seager, J., Sánder, F., et al. (2020). Re-imagining the driver-pressure-state-impact-response framework from an equity and inclusive development perspective. Sustainability Science, 15, 503-520. https://doi.org/10.1007/s11625-019-00708-6.

Herforth, A., Frongillo, E. A., Sassi, F., Mclean, M. S., Arabi, M., Tirado, C., et al. (2014). Toward an integrated approach to nutritional quality, environmental sustainability, and economic viability: Research and measurement gaps: Integrating nutritional quality, environmental sustainability, and economic viability. Annals of the New York Academy of Sciences, 1332, 1-21. https://doi.org/10.1111/ nyas. 12552 .

Holden, S. T., \& Otsuka, K. (2014). The roles of land tenure reforms and land markets in the context of population growth and land use intensification in Africa. Food Policy, 48, 88-97. https://doi. org/10.1016/j.foodpol.2014.03.005.

Hospes, O., \& Brons, A. (2016). Food system governance. A systematic literature review. In A. Kennedy \& J. Lilijeblad (Eds.), Food systems governance. Challenges for justice, equality and human rights (pp. 13-42). London: Routledge.

Howard, P. H. (2016). Concentration and power in the food system: who controls what we eat? Contemporary food studies: economy, culture and politics. London: Bloomsbury Academic.

Jobbins, G., Kalpakian, J., Chriyaa, A., Legrouri, A., \& El Mzouri, E. H. (2015). To what end? Drip irrigation and the water-energy-food nexus in Morocco. International Journal of Water Resources Development, 31, 393-406. https://doi.org/10.1080/07900627.2015.1020146.

Kalfagianni, A. (2015). 'Just food'. The normative obligations of private agrifood governance. Global Environmental Change, 31, 174-186. https://doi.org/10.1016/j.gloenvcha.2015.01.007. 
Kalfagianni, A., \& Skordili, S. (2019). Localizing global food: short food supply chains as responses to agri-food system challenges. London: Routledge.

Keesstra, S., Mol, G., de Leeuw, J., Okx, J., Molenaar, C., de Cleen, M., et al. (2018). Soil-related sustainable development goals: Four concepts to make land degradation neutrality and restoration work. Land, 7, 133. https://doi.org/10.3390/land7040133.

Kelman, I. (2017). Linking disaster risk reduction, climate change, and the sustainable development goals. Disaster Prevention and Management: An International Journal, 26, 254-258. https://doi. org/10.1108/DPM-02-2017-0043.

Kennedy, A., \& Lilijeblad, J. (2016). Food Systems Governance. Challenges for justice, equality and human rights. London: Routledge.

Koh, L. P., \& Ghazoul, J. (2008). Biofuels, biodiversity, and people: Understanding the conflicts and finding opportunities. Biological Conservation, 141, 2450-2460. https://doi.org/10.1016/j.bioco n.2008.08.005.

Lang, T., \& Barling, D. (2012). Food security and food sustainability: Reformulating the debate: Food security and food sustainability-reformulating the debate. The Geographical Journal, 178, 313-326. https://doi.org/10.1111/j.1475-4959.2012.00480.x.

Leck, H., Conway, D., Bradshaw, M., \& Rees, J. (2015). Tracing the water-energy-food nexus: description, theory and practice: Tracing the water-energy-food Nexus. Geography Compass, 9, 445-460. https://doi.org/10.1111/gec3.12222.

Lesk, C., Rowhani, P., \& Ramankutty, N. (2016). Influence of extreme weather disasters on global crop production. Nature, 529, 84-87. https://doi.org/10.1038/nature16467.

Leventon, J., \& Laudan, J. (2017). Local food sovereignty for global food security? Highlighting interplay challenges. Geoforum, 85, 23-26. https://doi.org/10.1016/j.geoforum.2017.07.002.

Lipton, M. (2009). Land reform in developing countries: property rights and property wrongs Routledge priorities in development economics. New York, NY: Routledge.

Lipton, M., \& Saghai, Y. (2017). Food security, farmland access ethics, and land reform. Global Food Security, 12, 59-66. https://doi.org/10.1016/j.gfs.2016.03.004.

Lobell, D. B., Burke, M. B., Tebaldi, C., Mastrandrea, M. D., Falcon, W. P., \& Naylor, R. L. (2008). Prioritizing climate change adaptation needs for food security in 2030. Science, 319, 607-610.

Lowder, S. K., Skoet, J., \& Raney, T. (2016). The number, size, and distribution of farms, smallholder farms, and family farms worldwide. World Development, 87, 16-29. https://doi.org/10.1016/j. worlddev.2015.10.041

Machovina, B., Feeley, K. J., \& Ripple, W. J. (2015). Biodiversity conservation: The key is reducing meat consumption. Science of The Total Environment, 536, 419-431. https://doi.org/10.1016/j. scitotenv.2015.07.022.

Maetz, M., Aguirre, M., Sunae, K., Yasaman, M., Guendalina, P., \& Valentina, P. (2011). Food and agricultural policy trends after the 2008 food security crisis. Renewed attention to agricultural development (EASYPol Module 125). Resources for Policy Making Applied Work. Rome: FAO.

Margulis, M. E. (2012). Global food security governance: The committee on world food security, comprehensive framework for action and the G8/G20. In R. Rayfuse \& N. Weisfelt (Eds.), The challenge of food security: International policy and regulatory frameworks (pp. 231-254). Cheltenham: Edward Elgar.

Margulis, M. E. (2013). The regime complex for food security: Implications for the global hunger challenge. Global Governance: A Review of Multilateralism and International Organizations, 19, 53-67. https://doi.org/10.1163/19426720-01901005.

Markelova, H., \& Mwangi, E. (2010). Collective Action for smallholder market access: Evidence and implications for Africa: Collective action for smallholder market access. Review of Policy Research, 27, 621-640. https://doi.org/10.1111/j.1541-1338.2010.00462.x.

McKeon, N. (2011). Global governance for world food security: A scorecard four years after the eruption of the food crisis. Berlin: Heinrich Böll Foundation.

McMichael, P. (2014). Rethinking 'Food Security' for the New Millennium: Sage Advice. Sociologia Ruralis, 54, 109-111. https://doi.org/10.1111/soru.12038.

Meyfroidt, P., Lambin, E. F., Erb, K.-H., \& Hertel, T. W. (2013). Globalization of land use: Distant drivers of land change and geographic displacement of land use. Current Opinion in Environmental Sustainability, 5, 438-444. https://doi.org/10.1016/j.cosust.2013.04.003.

Moragues-Faus, A. (2017). Problematising justice definitions in public food security debates: Towards global and participative food justices. Geoforum, 84, 95-106. https://doi.org/10.1016/j.geofo rum.2017.06.007.

Murphy, S., Burch, D., \& Clapp, J. (2012). Cereal secrets: The World's largest grain traders and global agriculture (Oxfam Research Reports). 
Newell, D. G., Koopmans, M., Verhoef, L., Duizer, E., Aidara-Kane, A., Sprong, H., et al. (2010). Foodborne diseases-The challenges of 20 years ago still persist while new ones continue to emerge. International Journal of Food Microbiology, 139, S3-S15. https://doi.org/10.1016/j.ijfoodmicr o.2010.01.02.

Nilsson, M., \& Persson, Å. (2012). Can Earth system interactions be governed? Governance functions for linking climate change mitigation with land use, freshwater and biodiversity protection. Ecological Economics, 75, 61-71. https://doi.org/10.1016/j.ecolecon.2011.12.015.

Nolte, K., Chamberlain, W., \& Giger, M. (2016). International land deals for agriculture. Fresh insights from the land matrix: analytical report II. German Institute of Global and Area Studies. Bern: University of Pretoria.

Obersteiner, M., Walsh, B., Frank, S., Havlík, P., Cantele, M., Liu, J., et al. (2016). Assessing the land resource-food price nexus of the Sustainable Development Goals. Science Advances, 2, e1501499. https://doi.org/10.1126/sciadv.1501499.

Olomola, A. (2013). Policy options for agricultural investments and gover-nance of markets: In support of small-scale agriculture in Nigeria, Oxfam Research Report.

Olson, J., Clay, P. M., \& Pinto da Silva, P. (2014). Putting the seafood in sustainable food systems. Marine Policy, 43, 104-111. https://doi.org/10.1016/j.marpol.2013.05.001.

Oxfam. (2016). An economy for the 1\%: How privilege and power in the economy drive extreme inequality and how this can be stopped. Oxford: Oxfam GB.

Oxfam. (2016). International land coalition, rights and resources initiative. Common ground. securing land rights and safe-guarding the earth. Oxford: Oxfam GB.

Pahl-Wostl, C. (2019). Governance of the water-energy-food security nexus: A multi-level coordination challenge. Environmental Science \& Policy, 92, 356-367. https://doi.org/10.1016/j.envsci.2017.07.017.

Pérez-Escamilla, R. (2017). Food security and the 2015-2030 sustainable development goals: From human to planetary health: perspectives and opinions. Current Developments in Nutrition, 1, e000513. https ://doi.org/10.3945/cdn.117.000513.

Phiri, A., Chipeta, G. T., \& Chawinga, W. D. (2019). Information needs and barriers of rural smallholder farmers in developing countries: A case study of rural smallholder farmers in Malawi. Information Development, 35, 421-434. https://doi.org/10.1177/0266666918755222.

Poesen, J. (2018). Soil erosion in the Anthropocene: Research needs-Soil erosion in the Anthropocene. Earth Surface Processes and Landforms, 43, 64-84. https://doi.org/10.1002/esp.4250.

Rasul, G. (2016). Managing the food, water, and energy nexus for achieving the Sustainable Development Goals in South Asia. Environmental Development, 18, 14-25. https://doi.org/10.1016/j.envde v.2015.12.001.

Rees, J. (2013). Geography and the nexus: Presidential Address and record of the Royal Geographical Society (with IBG) AGM 2013-Presidential Address and record of the RGS-IBG AGM 2013. The Geographical Journal, 179, 279-282. https://doi.org/10.1111/geoj.12050.

Richardson, R. B. (2010). Ecosystem services and food security: Economic perspectives on environmental sustainability. Sustainability, 2, 3520-3548. https://doi.org/10.3390/su2113520.

Ringler, C., Bhaduri, A., \& Lawford, R. (2013). The nexus across water, energy, land and food (WELF): Potential for improved resource use efficiency? Current Opinion in Environmental Sustainability, 5, 617-624. https://doi.org/10.1016/j.cosust.2013.11.002.

Rulli, M. C., Bellomi, D., Cazzoli, A., De Carolis, G., \& D’Odorico, P. (2016). The water-land-food nexus of first-generation biofuels. Scientific Reports. https://doi.org/10.1038/srep22521.

Seligman, H. K., Laraia, B. A., \& Kushel, M. B. (2010). Food Insecurity is associated with chronic disease among low-income NHANES participants. The Journal of Nutrition, 140, 304-310. https://doi. org/10.3945/jn.109.112573.

Sen, A. (1981). Poverty and famines: an essay on entitlement and deprivation. New York: Clarendon Press.

Sikor, T., He, J., \& Lestrelin, G. (2017). Property rights regimes and natural resources: A conceptual analysis revisited. World Development, 93, 337-349. https://doi.org/10.1016/j.worlddev.2016.12.032.

Smith, P., \& Gregory, P. J. (2013). Climate change and sustainable food production. Proceedings of the Nutrition Society, 72, 21-28. https://doi.org/10.1017/S0029665112002832.

Sorda, G., Banse, M., \& Kemfert, C. (2010). An overview of biofuel policies across the world. Energy Policy, 38, 6977-6988. https://doi.org/10.1016/j.enpol.2010.06.066.

Terlau, W., Hirsch, D., \& Blanke, M. (2018). Smallholder farmers as a backbone for the implementation of the Sustainable Development Goals. Sustainable Development, 27, 523-529. https://doi.org/10.1002/ sd.1907.

Tilman, D., Balzer, C., Hill, J., \& Befort, B. L. (2011). Global food demand and the sustainable intensification of agriculture. Proceedings of the National Academy of Sciences, 108, 20260-20264. https://doi. org/10.1073/pnas.1116437108. 
Tilman, D., Socolow, R., Foley, J. A., Hill, J., Larson, E., Lynd, L., et al. (2009). Beneficial Biofuels-The Food, Energy, and Environment Trilemma. Science, 325, 270-271. https://doi.org/10.1126/scien ce. 1177970 .

Tomei, J., \& Helliwell, R. (2016). Food versus fuel? Going beyond biofuels. Land Use Policy, 56, 320-326. https://doi.org/10.1016/j.landusepol.2015.11.015.

UNCCD. (2017). Global land outlook. Germany: Bonn.

UNDP. (2005). Halving hunger: It can be done-summary version UN Millennium Project. Task Force on Hunger. New York: UNDP.

UNGA. (2015). A/RES/70/1.

United Nations (2000). A/RES/55/2 United Nations Millennium Declaration.

Vandergeest, P. (2017). Transnational sustainability certification as a new extraterritoriality? In C. Antons (Ed.), Routledge handbook of Asian Law (pp. 271-286). New York: Routledge.

Vermeulen, S. J., Campbell, B. M., \& Ingram, J. S. I. (2012). Climate change and food systems. Annual Review of Environment and Resources, 37, 195-222. https://doi.org/10.1146/annurev-environ-02041 1-130608.

Warnecke, T. (2015). “Greening” Gender Equity: Microfinance and the Sustainable Development Agenda. Journal of Economic Issues, 49, 553-562. https://doi.org/10.1080/00213624.2015.1042803.

Weitz, N., Strambo, C., Kemp-Benedict, E., \& Nilsson, M. (2017). Closing the governance gaps in the water-energy-food nexus: Insights from integrative governance. Global Environmental Change, 45, 165-173. https://doi.org/10.1016/j.gloenvcha.2017.06.006.

Whitmee, S., Haines, A., Beyrer, C., Boltz, F., Capon, A. G., de Souza Dias, B. F., et al. (2015). Safeguarding human health in the Anthropocene epoch: report of The Rockefeller Foundation-Lancet Commission on planetary health. The Lancet, 386, 1973-2028. https://doi.org/10.1016/S0140-6736(15)60901 -1 .

World Bank. (2015). Ending poverty and hunger by 2030: An agenda for the global food system. Washington, DC: World Bank.

World Bank. (2008). Agriculture for development. Washington, DC: World Bank.

WWF. (2016). Living Planet Report 2016 Risk and resilience in a new era. Gland: WWF International.

Zelli, F., \& van Asselt, H. (2013). Introduction: The institutional fragmentation of global environmental governance: causes, consequences, and responses. Global Environmental Politics, 13, 1-13. https:// doi.org/10.1162/GLEP_a_00180.

Publisher's Note Springer Nature remains neutral with regard to jurisdictional claims in published maps and institutional affiliations. 